\title{
LEGAL PROTECTION OF THE FAMILY: ESSENTIAL POLISH PROVISIONS REGARDING INTERNATIONAL LEGAL STANDARDS AND SOCIAL CHANGE
}

MAREK ANDRZEJEWSKI

\section{Introduction}

This article represents an overview of the most significant problems associated with legal protection of the family in Poland while taking into account the influence of various new social, political, and legal phenomena taking place in the Euro-American cultural sphere, which includes Central Europe, and thus Poland. The main subject of the overview is the Polish law in force, which is described and discussed against universal and European legal standards that were cataloged half a century ago. What now is more or less openly questioned is the interpretation of the Polish law that is rooted in values hitherto commonly shared in the western culture.

Developments of legal institutions dealing with legal protection of the family have caused fierce controversies, primarily as the result of changes taking place in the Family and Guardianship Code (hereafter referred to as FGC), diverse acts in the constitutional, administrative, and procedural law, and many international documents ratified by Poland (in doctrine all the documents are referred to as law referring to the family). ${ }^{1}$

1 Ziembiński, 1982, p. 126; Andrzejewski, 2003, pp. 51-61; Telusiewicz, 2013.

Marek Andrzejewski (2021) Legal Protection of the Family: Essential Polish Provisions Regarding International Legal Standards and Social Change. In: Tímea Barzó, Barnabás Lenkovics (eds.) Family Protection From a Legal Perspective, pp. 151-190. Budapest-Miskolc, Ferenc Mádl Institute of Comparative Law-Central European Academic Publishing. 
These controversial issues are often the axes of scientific disputes (philosophical, psychological, and legal) and subsequent political divisions, thus becoming a distinguishing factor in classifying a politician as liberal, socialist, conservative, a supporter or an opponent, or of other political leanings. Indeed, these issues feature prominently in presidential, parliamentary, or local elections. Among them we often find such disputes as the (in)admissibility of abortion and euthanasia, the nature of regulations on the institution of marriage and other forms of permanent relationships, the availability of divorce, the nature of adoption, the legal position of parents regarding children, and the legal position of the state regarding the family. These controversial topics generate intense philosophical, political, and legal disagreement that gives rise to conflict among the general public.

The gravity of the issues touched upon in the overview is connected with the fact that in Western and Central Europe, and to a certain extent in Eastern Europe, the right to freedom of travel, and thus the freedom to choose which country one works and lives in, is generally respected. Under the conditions of a free flow of people, it is not uncommon that people establish personal relationships with citizens of different countries. Such contacts are also fostered by the existence of and cooperation between international social, economic, and political institutions. In this way, a special context that is conducive to establishing family relationships between people from different parts of the European continent has been created. However, in addition to the many advantages arising from this state of affairs, such relationships also generate legal disputes on an unprecedented scale. Naturally, the involvement of foreign elements in solving family legal problems tends to make them more difficult to resolve.

Family-related issues also entail a political aspect, manifested in the fact that some European states and member state organizations create pressure to impose certain regulations on family law in other states, regardless of their obligation/or commitment, politically declared and formulated in international documents, to respect different regulations adopted in individual states regarding family protections. This creates tensions between Western Europe, where so-called "progressive" views on the family and quasi-family issues dominate, and some Central European countries, in which the so-called "conservative" perception of family prevails.

The perception of marriage and family and of their role in society has recently become the axis of civilizational dispute. ${ }^{2}$ The so-called "conservatives" consider marriage a union of a man and a woman, abortion an evil only exceptionally permissible, euthanasia a disgrace, divorce a dissolution of marriage to be granted only once certain conditions have been met, raising children the domain of their parents, and adoption an imitation of natural relationships. The so-called "progressive" leftists and those in the liberal camp, whose understanding of the family is anchored primarily in the ideology of gender, may claim that those seeking to marry should be entirely unrestricted with regard to gender or the state of consciousness of the 
future spouses; that divorce should be dependent on the will of the spouses and thus be unrestricted; that a mother should have unrestricted access to abortion; and that the liberal state may undermine the primary role of parents in raising children. In this dispute, Poland has its own unique experience that is reflected in debate and legislation, and all legal regulations are a function of long-term scientific reflection and political dispute. Hence, it is difficult to predict what the future effects of the discussions and changes will be.

\section{Marriage and the family: Symptoms of evolution or a crisis?}

\subsection{Introductory remarks}

Countries belonging to the western European cultural circle continue to witness several similar social processes that have a destabilizing effect on the functioning of families. These processes vary in intensity from country to country due, inter alia, to each country's unique societal traits', its political history, the level of its economic development, and the role of religious, social, and moral norms. These processes, which began in Western European countries, have spread over time to Central European societies. There, the effect of the processes has, thus far, been less forceful because the so-called "threats" were diagnosed in time and some counter-measures were taken. However, because the societies of Central European countries are greatly or slightly different, they have different outlooks: some are less susceptible to the currents of thought anchored in the philosophy of the Enlightenment. Moreover, they are less susceptible to neo-Marxist influences (e.g., new definitions and policies on gender).

A crisis of the family has been widely discussed in world literature, especially in the field of sociology. ${ }^{3}$ One must agree that this crisis truly exists. Its symptoms should be monitored and remedial measures sought, and, most importantly, its scale should not be overestimated. The family undergoes changes, but endures. Its weaknesses and its perception of the threats it faces are integral to the nature of its existence. Thus, the symptoms of the family crisis, especially pronounced in Western Europe, are not, and need not be, equally destructive in the countries of Central Europe, including Poland. ${ }^{4}$

In what follows the most significant symptoms of the crisis in family life and marriage in Europe today will be presented. Other issues such as abortion, the trivialization of marriage, and domestic violence will be discussed in later sections.

3 Szlendak, 2010, pp. 363-391; Adamski, 2002, pp. 175-193; Kocik, 2006, pp. 353-384.

4 Przybył, 2012, p. 31. 


\subsection{Demographic changes}

Europe continues to face enormous and mostly unfavorable demographic changes ${ }^{5}$ that began in the 19th century with the evolution of the way the family and societies functioned. The key factors in this process have been a high standard of living for European societies and their focus on the so-called "quality of life," which is presumably easier to achieve with fewer children. Other factors at play include, among others, secularization and the increasing professional advancement of women. ${ }^{6}$ The aforementioned increased economic wealth contributes to a longer lifespan for both women and men, which, together with a lower reproductive rate, leads to a greater proportion of elderly people in the population. This, in turn, necessitates the development of geriatric medicine, the development of social care services, and a reform of pension systems.

The birth rate in Poland has remained extremely low since the mid-1990s. The reproductive rate required to achieve a simple replacement of the generations, i.e., the average number of children born to a woman during her reproductive period, between 15 to 49 years of age, is 2.1, while over the last two decades this rate has been approximately $1.36-1.40$ in Poland (ranking $212^{\text {th }}$ of 224 countries $^{7}$ ). ${ }^{8}$ This generates many problems, not only for the stability of the labor market (almost a million foreigners work legally in Poland, mainly citizens of the Ukraine) but also for the Polish pension system. ${ }^{9}$

\subsection{Marriage and divorce}

In Europe, marriage tends to be less common while the opposite is true of divorce. ${ }^{10}$ In the context of the sociology of the family, the term "de-institutionalization of marriage" has been coined to describe the conduct of partners who-motivated by such values as individualism, the right to privacy, and an aversion to the customs and obligations traditionally associated with family life-choose to co-habit in relationships alternative to marriage such as cohabitation, civil partnerships, and same-sex relationships. The assumption in these relationships is that they last as long as the relationship brings satisfaction to both parties and provides a sense of fulfillment and self-realization. In this context, marriage, as a permanent relationship with its attendant obligations independent of the emotional state of the participants, appears restrictive. A relationship based solely on an emotional bond is, however, by definition less stable and less permanent. ${ }^{11}$ Despite the decline in the status and

5 Strzelecki, 2015, pp. 42-66.

6 Golinowska, 1994, pp. 116-147.

7 The World Factbook, 2012, Available at: https://bit.ly/3mnhlmA (Accessed: 25 April 2021).

8 Szukalski, 2009, pp. 59-75.

9 Golinowska, 1994, pp. 70-77.

10 Cierniak-Piotrowska et al., 2019, pp. 151-157.

11 Kwak, 2007, p. 37. 
importance of marriage, its symbolic significance remains clear: it is still seen as an indicator of prestige and personal achievement. ${ }^{12}$

It has been observed that the above processes that weaken marital ties and which are widely observed in Western Europe have a lesser impact on more conservative societies, an example of which is Poland. ${ }^{13}$ However, due to wider access to higher education and a sense of instability (caused by factors such as a lack of housing and a high unemployment rate until 2015) the age at which people tend to marry in Poland has also increased over the last three decades: from around 20 for women and 22 for men to around 28 and 30, respectively.

Another characteristic feature of family life in Europe is the increase in the divorce rate over the last five decades. In Poland, the number of divorces remained unchanged at around 40,000 annually between the 1960s and the 1990s, but increased dramatically in the middle of the first decade of the $21^{\text {st }}$ century to the current level of approximately 65,000 divorces annually. ${ }^{14}$ All told, about 2.5 million people in Poland have divorced in the 21 st century ( $7 \%$ of the adult population).

\subsection{Migrations}

Migration patterns, both past and present, have often led to disruption in the newcomers' family life and sometimes to a breakdown of family ties. ${ }^{15}$ Immigration also affects the family life in those societies that host immigrants. Economic migration is a fact of life for between 2 and 3 million Poles who live and work in Great Britain, Ireland, and other European Union nations. Although it is not as intense as in other European countries, economic migration in Poland has destabilized family life. Immigration is often a necessity, whether economic or political, rather than an individual's free choice. This factor notwithstanding, the non-economic effects of immigration on the stability of the family must be considered.

Migration also generates cross-border issues that affect family life. Among these issues we find the breakdown of marriage and the decisions of different family members to settle in different countries.

\subsection{Women's emancipation and empowerment}

One factor that significantly affects the structure and well-being of the family is women's emancipation, which implies that on average women's current levels of education are higher than those of men, and women are more present in the labor market than before. ${ }^{16}$ The root cause of this emancipation process is the idea of

12 Cherin, 2004; Glynn, 2013.

13 Ostaszewska-Nagórka, 2012, pp. 35-58; Przybył, 2012, pp. 13 ff.

14 Report of Centre for Public Opinion Research, 2019. Available at: https://bit.ly/3iCfoBS.

15 Danilewicz, 2010; Becker-Pestka, 2012, pp. 9-26.

16 Dyczewski, 1994, pp. 67-89; Kawula, 2005, pp. 97-111. 
equality between women and men, which is the current standard adopted in the constitutions of European countries (Art. 30 of The Constitution of the Republic Poland; hereafter referred as The Constitution). In addition to the changes in constitutional law, emancipation and equality have given rise to a number of implications for other areas of law, especially family law (particularly Art. 23 FGC, but also provisions on property and matrimonial regimes and equal status of both parents regarding their children) and labor law (Art. 183a Labor Code). ${ }^{17}$

As a result of emancipation, women choose different pathways for personal fulfillment. This has had a decisive impact on the way family members fulfill their roles in the modern family in such areas as family finances and the provision of care and child-rearing (more institutional support is provided for parents in the form of nurseries, kindergartens, community clubs, and school clubs, for instance). ${ }^{18}$ Emancipation and subsequent professional participation of women in the labor market is also one reason for the decline in the family fertility rate.

Women's emancipation and empowerment-obvious, inevitable, and favorable for civilization-must have led to a marriage crisis, especially in unions where men still function according to rules that govern families with a so-called "traditional" division of roles.

\subsection{Secularization}

Secularization is an important trigger for social change, including those changes affecting the form and well-being of the family. Initiated by the Reformation, secularization went on to expand and was strengthened by the ideas of the Enlightenment, whose influence endures. ${ }^{19}$

The struggle against the Catholic Church and religion in general, waged by communists in Central Europe ${ }^{20}$ after World War II, led to the secularization of those directly and indirectly involved in the communist system, both politically and economically. However, unlike in other East European countries where large parts of society were secularized, in Poland resistance to communism actually resulted in strengthening religiosity and adherence to Catholic Church in a large section of society. It must be added the role of church in Polish society had been particularly strong after Poland regained independence in 1918 because during partitions (17951918) the Catholic Church had often been the pillar of Polishness.

Secularization did not gain force in Poland until 1989. However, in recent years, the influence of religious institutions on Polish society has been weakening, religious participation has declined, and behavior that defies the moral and social teachings of

17 Labor Code of 26 June 1974, consolidated text (hereinafter ct.): Journal of Laws of 2020, Item 1320.

18 Szlendak, 2010, p. 117; Kwak, 2007, p. 37.

19 Adamski, 1987, pp. 63-94.

20 Cywiński, 1990. 
the Catholic Church and other Christian churches on such issues as divorce, alcohol abuse, abortion, and domestic violence has increased in frequency and visibility. ${ }^{21}$

On the other hand, the formation of communities and groups of conscious faith followers, such as the neo-catechumenate, Opus Dei, and the Light-Life Movement, whose every aspect of life is guided by religious principles, is worth noting. This is mostly manifested in the approach of these groups to family, i.e., in terms of fertility, the roles of the spouses in marriage, the way parental rights are exercised, and in the establishment of kindergartens and schools that guarantee an education in accordance with the parents' beliefs, etc.

"Relations between the state and the Church and other religious institutions are based on respect for their autonomy and independence each in their own domain, as well as on co-operation for the good of man and the common good" (Art. 25 (3) of The Constitution). The foundation for the co-operation between the Catholic Church and Polish state authorities is the Concordat, i.e., the international agreement ratified between Poland and the Holy See on July 28, 1993. ${ }^{22}$ Some of its regulations concern family issues, for example, the solemnization of marriage in civil registers, the organization of burials, the religious education of children, and church organizations, many of which deal with many problems concerning the family. According to the constitutional principle of autonomy, declaring a religious marriage null and void falls within the ambit of Church authorities, and granting divorce to those couples whose weddings were performed in a denominational form that has consequences for secular law is the prerogative of the common courts (Art. 10 of the Concordat). ${ }^{23}$ The state ensures that religion be taught in kindergartens and state schools in accordance with the will of the parents (Art. 12 of the Concordat), and the Church has the right to establish its own educational institutions in accordance with the applicable law.

Numerous church institutions are involved in charity (e.g., Caritas Polska), education (kindergartens, schools, and colleges), and child-rearing and adult care (child care facilities, nursing homes). Family counseling centers are organized in parishes and provide help regarding psychology, pedagogy, law, and pastoral care with a special focus on families. Pre-marriage courses for prospective spouses are an example of other educational activities.

\subsection{Sexualization}

Sexualization is defined as "bestowing sexual meaning (which is seen as socially and culturally inadequate), to stimuli, people, or situations that have no such inherent meaning in a culture, or whose meaning is more complex; thus, sexualization

23 Smyczyński, 1997a; Ignatowicz, Nazar, 2016, pp. 197-203; Gajda, 2009, pp. 112-137. 
involves assigning excessive attention to sexuality." ${ }^{24}$ This phenomenon may be traced back to the sexual revolution of the 1960s.

The destructive influence of sexualization on the development of irresponsible attitudes in sexual behavior cannot be questioned. This is further influenced by the pornography industry, whose products are now readily accessible, even to children. Another factor that has contributed to the development of sexualization is the focus in sex education on the physical and technical aspects of sex, with disregard for its ethical dimension. ${ }^{25}$ Such an approach to sex leads to a reduction of the age of consent and to adolescent motherhood. ${ }^{26}$ Moreover, any discussion on sexualization should not fail to mention the wide scale of pedophilia and other cases of sexual abuse and crimes.

\section{Protection of marriage and the family: International standards}

\subsection{Universal standards}

Documents detailing the standards for the protection of human rights emphasize the significance of the family and marriage, and, by extension, such issues as the primacy of parents in raising their children, the right to privacy, and the responsibility of the state towards the family. Such documents clearly buttress the so-called "conservative" attitude towards the family. ${ }^{27}$

Among the universal standards for the protection of marriage and the family, the most important argument for the need to protect this institution can be found in Article 16, Sec. 1 of the United Nations Universal Declaration of Human Rights of December 10,1948, specifically the statement that marriage and the establishment of a family are the rights of men and women. The authors certainly did not anticipate that this statement, derived from the inherent dignity of a person, would, half a century later, become an argument used to protect the identity of marriage as a heterosexual union. It should be emphasized here that the concept of marriage as the union of a man and a woman has never been and is not an expression of discrimination against homosexuals but rather results from the nature of the marriage, described from the point of view of biology, anthropology, and sociology of the family as a fertile union whose social function is procreation. ${ }^{28}$

24 Zielona-Jenek, 2017, p. 23; Waszyńska, Zielona-Jenek, 2016, pp. 351-376.

25 Cube, 2013.

26 Maciarz, 2004, Izdebski, Niemiec, Wąż, 2011.

27 Smyczyński, 1999, pp. 149-166.

28 Wiśniewski, 2009, pp. 157-162; Tyszka, 1997, pp. 59-60; Kocik, 2006, pp. 241-276. 
Article 23, Sec. 1 of the United Nations International Covenant on Civil and Political Rights of December 16, 1966 defines the family as the natural and basic social unit that should be protected by the general public and the state. Such an understanding is rooted in the philosophy of Aristotle and Auguste Comte, who perceived society as an organism consisting of different cells, the most basic of which is the family unit. Such an approach imposes on a state an obligation to conduct a social policy that benefits families and society as a whole by designing various support programs targeted at families. ${ }^{29}$

The UN Convention of November 20, 1989 is one of the most important universal documents that addresses family issues and the rights of the child. ${ }^{30}$ In this landmark document, children are perceived as having rights conferred upon them by virtue of the inherent dignity of a person, the source of these rights being dignity rather than the state. ${ }^{31}$ The adoption of the Convention represented a turning point in the discussion on children; specifically concerning their legal status. The breakthrough was evident in the fact that the Convention treats children as family members and parents as responsible for children's development, having primacy in their upbringing and entitled to support from public institutions. This document was rooted in a philosophy that emphasizes the community (social group) dimension of humanity, specifically the family. Nearly all the provisions of the Convention (especially the preamble and Articles 5, 7, and 18) suggest this community aspect of the family; the conclusion may thus be drawn that children have the right to live in a family. The Convention therefore sends a message addressed to the signatory states that in order to ensure proper protection of children's rights, families must be supported. Hence, the Convention may be seen as a family-friendly document. ${ }^{32}$

The December 13, 2006 UN Convention on the Rights of Persons with Disabilities $^{33}$ also contains provisions for family situations for such persons. Article 23 obliges states to eliminate discrimination against people with disabilities in all matters relating to marriage, family, parenthood, and relationships, ensuring "recognition of the right of all persons with disabilities who are of marriageable age to marry and to found a family, on the basis of free and full consent of the intending spouses; [...] to decide freely and responsibly on the number and spacing of their children," $[. .$.$] and to "maintain their fertility on an equal basis with others." This$ law delineates the obligation of the state to provide persons with disabilities appropriate support to enable them to raise children. ${ }^{34}$

An inherent obligation in the provisions of the Convention to treat persons with severe mental disorders on an equal basis with healthy persons results from the conviction of their subjectivity. Such treatment, a civil obligation of people and

29 Tyszka, 1973, pp. 233-248.

30 Ct. Journal of Laws of 1991, Item 526.

31 Smyczyński, 1999b, pp. 39-48; Jaros, 2015, pp. 21-34.

32 Andrzejewski, 2012, pp. 41-46.

33 Journal of Laws of 2012, Item 1169.

34 Mikrut, 2015, Available at: https://bit.ly/3FmQlwp (Accessed: 20 April 2021). 
institutions towards more vulnerable members of society, need not lead to bestowing identical family rights and family-related legal obligations on them. Hence, the reservation entered by Poland to the above-mentioned provisions of the Convention constitutes no discrimination against those suffering from a severe mental disorder; on the contrary, it reflects their state of health and is intended to protect them and safeguard their interests. It should also be emphasized that the approach adopted by Poland towards marriage with regard to persons suffering from serious mental disorders is the embodiment of an international standard that requires the state to ensure that the consent to marriage is expressed consciously and voluntarily. ${ }^{35}$

Even in this brief review of universal legislation regarding the family, the conventions adopted by the Hague Conference, and in particular the Convention on the Civil Aspects of International Child Abduction (the Hague, October 25, 1980), ${ }^{36}$ warrant mentioning. Every year the number of cases relying on this act is increasing. It was drawn up during times characterized by free movement of people. Among these migrants, some would have established close relationships with citizens of different countries, had children with them, and separated in an atmosphere of dispute over who should have custody of the children, and hence, in which country those children should live. Disputes of this kind are already notoriously difficult to resolve when the spouses are citizens of the same country, so the foreign element only exacerbates the difficulty. Attempts to improve the method of resolving cases under this Convention to date have so far failed to produce results.

The Convention for the Protection of Children and Co-operation in the Field of International Adoption (the Hague, May 29, 1993), ${ }^{37}$ created a measure to protect children whose adoption involves moving to the country of their adoptive parents. This form of adoption is permissible in Poland if it has proved impossible to secure a foster family or an adoptive family in Poland.

\subsection{European Standards: Sources}

Since many Polish measures are functions of standards developed in a number of European documents, their content will not be discussed here, and only the content of some of them will be recounted. These documents are referenced below.

The European standard for the protection of marriage and the family arises from a number of documents (conventions, resolutions, and recommendations) of the Council of Europe, European Community regulations, and the jurisprudence of the European Court of Human Rights in Strasbourg.

35 Article 16(2) of the UN Universal Declaration of Human Rights, Article 23(3) of the United Nations International Covenant on Civil and Political Rights, Article 10(1) of the UN, International Covenant on Economic, Social and Cultural Rights, and Art. 1 of the Convention on Consent to Marriage, Minimum Marriageable Age and Marriage Registration). Journal of Laws of 1965, Item 53.

36 Journal of Laws of 1995, Item. 28.

37 Journal of Laws of 2000, Item 448. 
Of the documents prepared by the Council of Europe, the most important are the following: the European Convention for the Protection of Human Rights and Fundamental Freedoms, ${ }^{38}$ especially Articles 8 and 12; the judgments of the European Court of Human Rights in Strasbourg: ${ }^{39}$ the Adoption Convention; ${ }^{40}$ the Convention on Preventing and Combating Violence against Women and Domestic Violence (the Istanbul Convention); ${ }^{41}$ and the Convention on the Exercise of the Rights of the Child. ${ }^{42}$

The evolution of Polish family law after the 1989 political breakthrough was much impacted by the resolutions and recommendations of the Council of Europe on such issues as marital property regimes, parental authority (defined in the documents as parental responsibility), foster care, and social benefits for maintenance obligations. Although these documents are not formally binding for member states of the Council of Europe, they have become an important point of reference in the preparation of important amendments to the Family and Guardianship Code, especially those introduced in 2004, 2008, and 2011.

In the past two decades, several regulations of the European Union concerning formal law have been adopted; in particular Council Regulation (European Community; hereafter EC) No 2201/2003 of November 27, 2003 on the jurisdiction and the recognition and enforcement of judgments in matrimonial matters and matters of parental responsibility, ${ }^{43}$ repealing Regulation (EC) No. 1347/2000 (referred to as the new Brussels II); and Council Regulation (EC) No. 4/2009 of December 18, 2008, on jurisdiction, governing law, recognition and enforcement of decisions, and cooperation in matters relating to the maintenance obligations.

\subsection{International standards of protection of marriage and the family: Selected controversial issues}

\subsubsection{Ideological and semantic aspects of the disputes}

Modern popular philosophical and political concepts, such as post-modernism and gender ideology, tend to downplay the special role of the family in people's development as individuals and in the way societies function. In particular, the structure of the family as a group originating from marriage or an informal permanent relationship between a man and a woman is questioned while same-sex unions are treated as equally important, or sometimes more important. The positive treatment of and a positive attitude towards the latter become even more spectacular when they are displayed by people in prominent social and political positions such

38 Journal of Laws of 1993, Item 284.

39 Nowicki, 2010, pp. 508-556, 662-663.

40 Journal of Laws of 1999, Item 1,157.

41 Journal of Laws of 2015, Item 961.

42 Journal of Laws of 2000 , Item 1,128 .

43 OJ L 338, 23 December 2003. 
as heads of state, government ministers, and leaders of various national and international organizations. Such persons oftentimes seem to question even the semantic field used to describe the family; furthermore, concepts related to human sex such as man, woman, father, mother, boy and girl, are relativized. ${ }^{44}$

In modern literature, marriage and the family are described as being on a par with other alternative forms of unions, and the individual is emphasized over the community. More emphasis is also placed on the importance of the emotional ties one has with one's current significant other than on the permanent relationships governed by nature and law, the latter even at times depicted as oppressive. Society is therefore extremely confused about what constitutes the family, which in practice contributes to the weakening of family ties.

Noticing severe symptoms of semantic inroads in language and the way of life, as well as intellectual abuse in debates about the family, it should be emphasized that Poland remains a country where

1. the law regulates the marriage contract as being between a woman and a man (Art. 18 of The Constitution, Art. 1§1 FGC), i.e., persons of different sexes, and not, for example, by "two persons";

2. a mother, i.e., a woman, gives birth to a child (Art. $61^{9} \mathrm{FGC}$ ), i.e., a person of a specified sex; and

3. the presumption that the husband of the woman who gives birth to a child is the "father" of the child, and therefore is a man (Art. 62 FGC), just as a "father", i.e., is a man who acknowledges his paternity (Art. $72 \S 1$ and $73 \S 1$ FGC) in relation to a child born to an unmarried woman or whose paternity will be determined by the court (Art. 84 FGC).

A similar consistency may be observed in the use of terminology by Polish law in regulations concerning the legal situation of a child conceived but yet unborn. A child in the womb is defined as a "child" (Art. 927 of the Civil Code and Art. 2 of the Act of the Ombudsman for Children ${ }^{45}$ ). Moreover, if the word "fetus" appears, it is usually qualified by the adjective "human" (as defined by the January 7, 1993 Act on Family Planning, Human Embryo Protection, and Circumstances for Performing Abortion). The provisions on abortion use the term "pregnancy," most likely to mitigate the description of the act of killing a person (Art. 152 and 153 of Criminal Code, hereinafter $\mathrm{CrC}$ ).

\subsubsection{Domestic violence: Controversy over the Istanbul Convention}

The issue of domestic violence as defined in the Istanbul Convention is one example of a heated debate that has philosophical, ideological, and legal implications. Notwithstanding these disagreements, there is a common agreement that violence 
should be combatted. In Poland, however, opinions can be heard that the Istanbul Convention should be denounced on the grounds of its ideological profile, which presages a redefinition of concepts of the family in the spirit of gender ideology and ascribes generation and perpetuation of violence to traditional family. It should, therefore, be stressed that criticism of the Istanbul Convention from conservative circles is not dictated by their reluctance to combat the social ill that is domestic violence. In fact, Polish victims of domestic violence are protected to a much greater extent by the national law on domestic violence than by the Istanbul Convention.

\subsubsection{Erosion of the notion of human rights}

It has also become difficult to protect the family within the discourse on human rights as the significance of those rights has been relentlessly eroded. Over the last three decades the idea of human rights has been consistently undermined, among others by representatives of the academia. This is especially detrimental when an influential social group decides to refer to something as a human right and then demands that this alleged human right be respected by others. ${ }^{46}$ The doctrine of human rights "disseminated [...] throughout our civilization an atmosphere of infinite claims couched in the language of these rights. [...] All claims, whether justified or unjustified, rational or absurd, arising out of a real and painful scarcity or arising out of mindless envy, may be presented in our culture in terms of human rights and their violations." ${ }^{\prime 7}$ On a global scale, the profound thought of the Polish philosopher Leszek Kołakowski is well illustrated by acts undertaken in defense of human reproductive rights. On the one hand, reproductive rights refer to the right to adoption, including adoption by homosexual couples, and to artificial procreation, as a right to be provided and financed by the state, and on the other, to the right to have an abortion without requiring reasons or specifying time restrictions on when it can be performed (see 6.1.3). ${ }^{48}$

\subsubsection{State intervention into the parent-child relationship}

Disturbing changes may be observed in the relationship between the state and parents, in particular in some legal measures that undermine the primacy of parents in raising children as clearly spelled out in the Convention on the Rights of the Child. This is clear from a historical perspective, when both the constitution and ordinary laws of communist states, including those of Central Europe, contained regulations regarding both the primacy of the communist party in child-rearing and the subsequent obligation

46 Kołakowski, 2003; Bobko, 2021; Borkowicz, 2021; Freeman, 2002, pp. 11-12; Cornides, 2010, pp. 5-45.

47 Kołakowski, 2003.

48 Post-natal abortion (which is considered murder in Polish law) is the subject of serious debate (Art. $148 \mathrm{CrC}$ ). See: Giubilini, 2013, pp. 261-263. 
of parents to respect the child-rearing guidance issued by state authorities. Courts and administrative bodies complied with this direction, and as a result, interfered in the sphere of parental authority of parents who failed to respect this directive.

In contradiction to the standards that uphold the protection of human rights, many European countries today once more are passing regulations that undermine the importance of parents. This does not happen, however, in post-communist countries, but in the so-called "liberal" democracies of Western Europe. The legislative changes introduced may be seen in semantic shifts seen in modification of terminology, especially in the provisions on marital status or replacement of words such as father and mother by parent 1 and parent 2, terms stripped of their relation to sex Another example of such interference is regulations (or postulates for their introduction) that ignore parents' opinions on such issues as access to contraception, abortion for minors, and more recently, gender reassignment.

\section{Family and marriage in the light of the articles of The Constitution and the judgements of the Constitutional Tribunal of the Republic of Poland}

Many European countries' fundamental laws contain regulations on marriage and the family that refer to documents setting standards for the protection of marriage and family. The Constitution of April 2, 1997, which contains only a few provisions on this subject, is a good case in point.

\subsection{Protection of the family}

The article most frequently quoted in debates on family protection is Article 18 of the Constitution. The debates tend, however, to refer mainly to the one statement contained therein that marriage is a relationship between a man and a woman (see point 6.1.4). Of much less interest is the obligation this provision imposes on the state to provide protection and care for the family, motherhood, parenthood, and marriage. Article 71 of The Constitution, which obliges the state to enact a social and economic policy that takes into account the good of the family, especially those families in a difficult financial or social situation, is a constitutional specification of this obligation (for more on this subject, see point 4.1). It also spells out the state's duty to offer special assistance to families with many children and single-parent families, as well as providing support to mothers before and after giving birth.

With reference to the above-mentioned regulations, the Constitutional Tribunal of the Republic of Poland (hereinafter CT) ${ }^{49}$ ruled that provisions of the Act of No- 
vember 28, 2002 on family benefits ${ }^{50}$ concerning an allowance paid to single parents were inconsistent with Art. 18 and Art. 71, Sec. 1 of The Constitution. This social benefit was paid to unmarried, single, widowed, divorced, or separated persons who raised a child with the child's father or mother. At the same time, no provision was introduced to exclude cohabitating couples with children from being eligible. As a result, those cohabiting had an advantage in terms of access to benefits over married spouses raising children together. Thus, the regulation evaluated by the CT serves as an example of an unwise social law that weakened family ties. ${ }^{51}$

\subsection{Protection of human life}

The provision that has stirred up a tumult of emotions in Poland, creating social tensions and political dispute over the conditions for the admissibility of abortion, is Article 38 of The Constitution. This article ensures the legal protection of life for every human being. The reason abortion is discussed in the context of family life is that it concerns a child living in its mother's body, and this, indirectly, also applies to the child's relationship with the man who is the father. ${ }^{22}$

In its 1997 judgment, the CT took the stand that The Constitution should protect human life from conception. ${ }^{53}$ It enumerates, however, three exceptional circumstances that allow for the termination of a pregnancy. Under the Polish law, abortion was permissible if the conception of a child was a consequence of a punishable act, when the pregnancy endangered the mother's health and life, and if the child was permanently damaged. ${ }^{54}$

In its 22 October 2020 judgement, the CT ruled ${ }^{55}$ that the admissibility of performing abortion on the basis of the last premise is inconsistent with Arts. 38, 30, and 31, Sec. 3 of The Constitution, as it discriminates against persons with disabilities (see point 6.1.3). ${ }^{56}$

\subsection{Right to privacy and the parental authority in child rearing}

The privacy of family life and the right to make decisions about one's personal life are subject to constitutional protection (Art. 47 of The Constitution). In reality, however, the right to privacy is often forfeited. The clearest case in point is social networking sites, overflowing as they are with content related to family life, which

50 Ct. Journal of Laws of 2020, Item 111.

51 The effects are known from the experience of Scandinavian countries and policies implemented by the American Government in the 1970s towards the African Americans, in: Murray, 2001.

52 Haberko, 2010, pp. 111-182.

53 Judgement of the CT of 28 May 1987, K 26/96

54 Act of 7 January 1993 on family planning, the protection of the human fetus, and the admissibility of abortion. Journal of Laws of 1993, Item 78 with changes; Mazurkiewicz and Mysiak (eds.), 2017. 55 Judgement of the CT of 22 October 2020, sig. K 1/20.

56 Justification of the judgement in: Monitor Polski, 2021, Item 114. 
almost borders on exhibitionism. Of special concern can be a trend observed among parents, foster families, and even care and educational institutions of posting images of children on websites and social networks.

Article 48, Sec. 1 of The Constitution also grants parents primacy in the rearing of their children, which "should take into account the child's level of maturity, as well as the freedom of its conscience and religion and its beliefs." An element of this primacy is parents' freedom to choose schools other than state schools for their children (Art. 70, Sec. 3) (More about this in Sec. 2.3.4).

\subsection{Protection of children's rights ${ }^{57}$}

In Poland, children's rights are protected by The Constitution (Art. 72, Sec. 1). This acknowledges their importance, emphasized in the directive that "[e]veryone shall have the right to demand of the organs of public authority that they defend children against violence, cruelty, exploitation, and actions which undermine their moral sense." The Constitution also highlights two issues: first, the need to provide a child deprived of parental care with the assistance of public authorities (for foster care and adoption, see 8.3) and second, the obligation of public authorities and those responsible for the child to hear and, if possible, take into account the views of the child when considering matters directly or indirectly concerning the child (see 8.1).

\subsection{Provisions of the Family and Guardianship Code in the light of the jurisprudence of the Constitutional Tribunal of the Republic of Poland}

Many of the Constitutional Tribunal's important judgements have concerned family issues in the context of equality based on sex, of non-discrimination based on disability, and of the provision's inconsistency regarding subsidiarity. Relevant examples follow.

\subsubsection{Mental disability and marriage}

In its decision on the motion of the Ombudsman for a declaration of non-compliance of Art. 12 FGC with Art. 47 of The Constitution and Art. 23 of the United Nations Convention on the Rights of Persons with Disabilities (see 2.1), the CT disagreed with the applicant. ${ }^{58}$ It took the position that prohibiting a person suffering from significant mental disability resulting from a serious mental illness (at an advanced stage) or from a profound intellectual disability to get married, to which the aforementioned provision refers, does not discriminate against people with mental illnesses and/or disabilities. From the point of view of equality with regard to the 
right to marry, persons with mental disabilities are considered to be in a different position from those who are intellectually sound.

\subsubsection{Filiation}

In 2003 the CT questioned the lack of a procedural path in FGC for a man who considers himself to be the father of a child in cases for judicial establishment of paternity. ${ }^{59}$ The judgement was issued in a case initiated by the allegation that a man cannot recognize a child as his own unless the child's mother gives her consent (Art. 73 FGC ). This allegation was considered ineffective, since permission for such recognition on the basis of the man's statement alone would violate the child's mother's right to privacy (Art. 47 of The Constitution). The principle of equality before the law stipulates that a man (the alleged father) be allowed to bring a claim to the court to establish his own paternity (Art. 84 § 1 FGC). In another case, however, the Tribunal refused a man who considered himself to be a child's father the opportunity to seek the annulment of another man's recognition. ${ }^{60}$

In another judgement ${ }^{61}$, the CT found Art. 71 FGC unconstitutional, stating that denial of paternity after the death of a child is unacceptable. The verdict, which was questioned $^{62}$ in the Polish legal doctrine, was issued in the context of an exceptional situation of pending paternity proceedings for twins, one of whom died during the trial. The CT took the position that the deceased child would be affected by the verdict that would be given for its sibling.

Article $70 \S 1$ FGC was likewise found not to be in compliance with The Constitution "to the extent that it specifies the time limit for bringing an action for denial of the paternity of the mother's husband, regardless of the date when an adult child became aware that he or she was not fathered by his or her mother's husband." 63

\subsubsection{Foster children benefits}

In its judgement of February 26, $2003^{64}$ the CT questioned the practice that children in a foster family established by persons unrelated to the child received greater benefits than children in a foster family established by people related to them (in practice by grandparents or adult siblings). The argument supporting the practice was that the relatives belonged to a group obliged to provide support to the charge and thus should contribute to the costs of their maintenance.

59 Judgement of the CT of 28 April 2003, K 18/02.

60 Judgement of the CT of 17 April 2007, SK 20/05.

61 Judgement of the CT of 28 November 2013, P/33/12.

62 Smyczyński, 2018, pp. 205, 221-222.

63 Judgement of the CT of 16 May 2018, sig. SK 18/17

64 Judgement of the CT of 26 February 2003, sig. K/01; Judgement of the CT of 1 July 1996. sig. U. $3 / 95$. 
It was only in the judgement of 2012 issued on the grounds of a new regulation (Art. 80 of the Act on Supporting the Family and the System of Foster Care) ${ }^{65}$ that the CT interpreted the provisions of administrative law on the benefits for foster families together with the provisions FGC, and it found the difference in the amount of benefits allocated in maintenance for the two types of foster families mentioned above consistent with the constitutional principle of equality before the law. ${ }^{66}$ Apart from the key issue of proportionality, one of the arguments in support for the view is that social benefits for a child cannot exempt family members from maintenance obligations. ${ }^{67}$

\subsubsection{Disciplining child maintenance defaulters}

In two judgements, the CT ruled that those defaulting on maintenance payments should have their driver's licenses confiscated. This sanction is currently provided for in the Act of September 7, 2007 on assistance to persons entitled to alimony. ${ }^{68}$ In 2009, on the basis of a previously passed law, the CT decided that this sanction violated the principle of proportionality and defended the maintenance defaulters. ${ }^{69}$ In 2013, the case was heard again, as the above-mentioned sanction was reintroduced to the aforementioned Act. A slightly changed regulation served as a pretext to proceed with this case again, this time leading to the conclusion that confiscating a driver's license from a notorious maintenance defaulter is in accordance with Art. 2 of The Constitution (the principle of proportionality). ${ }^{70}$ This sanction was found to correspond to the degree of misconduct, in this case a persistent evasion of the axiologically strongly justified maintenance obligation. ${ }^{71}$

\section{Protection of marriage and family as a task of state social policy}

\subsection{Social and family policy}

In accordance with the provisions of The Constitution, a family is a relationship built on the foundation of marriage (i.e., a formally contracted marriage consisting of spouses with a child or children), which includes an incomplete family (as implied

65 Ct. Journal of Laws of 2020, Item 821.

66 Judgement of the CT of 23 April 2013, K 12/12.

67 Pietrzykowski, 2020, pp. 1037-1038.

68 Ct. Journal of Laws of 2020, Item 608.

69 Judgement of the CT of 22 September 2009, P 46/07.

70 CT Ruling 2 February 2014. Sign. K 23/10; Andrzejewski, 2015, pp. 168-198.

71 Boczek, 2017, pp. 115-128. 
directly by Art. 71 of The Constitution), irrespective of whether single parenthood is the result of the death of a spouse, divorce, abandonment, or a woman's conscious decision. In this sense, cohabiting couples with children also constitute a family, as described in Art. 18 of the Constitution. ${ }^{72}$

The relationship between the Polish state and families that may be inferred from the regulations adopted in The Constitution corresponds to a model that lies somewhere between the model suggested by libertarian and the communitarian views, ${ }^{73}$ i.e., a subsidiary state. ${ }^{74}$

The aforementioned Articles 18 and 71 of The Constitution oblige the state to promote an active social policy in favor of the family. In the context of family policy, i.e., social policy in relation to the family, Article 71 of The Constitution elucidates this general idea by imposing on the state an obligation to implement a social and economic policy that considers the good of the family, with a particular emphasis on supporting families in difficult material and social circumstances, especially singleparent and large families. The state's family policy is therefore specified in a number of legal regulations, acts, and measures, the aim of which is to create optimal conditions for families to thrive. ${ }^{75}$

\subsection{Issues with the constitutional principle of state subsidiarity}

From the beginning of the political transformation, attempts were made to create a Polish state that would support social groups in need, but in a way that would neither relieve them of their duties nor leave them to their own devices. ${ }^{76}$ Unfortunately, the model of the state outlined above aiming to ensure that welfare recipients eventually become independent was not consistently implemented. Social programs were not introduced in areas with structural unemployment, and low benefits rendered recipients dependent on them, creating the so-called "learned helplessness syndrome." In some areas, up to $30 \%$ of households fell victim to this syndrome. ${ }^{77}$ Due to the lack of a consistent policy of family social support, in the economic discourse of the $21^{\text {st }}$ century, a symbol of the Polish political transformation was a face of a poor child, an offspring of unemployed parents dependent on social benefits unable to provide good educational prospects for their child. ${ }^{78}$

Since 2015 there has been a visible departure of the state from a liberal social policy. Instead, the state has adopted a more active model towards social problems, in particular supporting the family through centralized social programs. The model currently implemented assumes, at least in the short term, no independence of those

72 Smyczyński, 1997a.

73 Morawski, 1998, pp. 26-42.

74 Andrzejewski, 2003, pp. 76-94.

75 Szudlińska-Kanoś, 2019, pp. 9-10.

76 Dylus, 1995; Millon-Delsol, 1995; Rymsza, 2003, pp. 19-32; Nitecki, 2008, pp. 95-102.

77 Czubkowska, Klinger, 2010, p. A8.

78 Domański, 2002, pp.73-79; Balcerzak-Paradowska, 1999; Balcerzak-Paradowska, 2009, pp. 39-45. 
families receiving a variety of benefits. The goal of the most spectacular social program, commonly known as $500+,{ }^{79}$ is not to make the beneficiaries independent, which is the most important aspect of the principle of subsidiarity, but to reduce significant areas of poverty. Analysis of the subsidiarity principle in the context of the legal protection of family, including intra-family relations, reveals that thanks to the comprehensive social support systems, especially in Western Europe and Scandinavia, the state, on the one hand, protects families against poverty, and on the other, takes on a familial role, providing the poor with the means to survive by redistributing funds raised from taxes. However, while it ensures that people living below the poverty line fulfill their economic duties, it simultaneously weakens family ties and even demobilizes and demoralizes family members, especially parents. The latter are in fact relieved of their economic duties towards their children, which runs contrary to the principle of subsidiarity.

\section{Institutional forms of protection of marriage and family}

\subsection{State and local government administration}

The Ministry of Family and Social Policy is an integral part of the government. Its nomenclature suggests that the ministry implements social policy in the context of the family. With the family in mind, various social programs are coordinated at the ministerial level. Some family-focused programs are also enacted by other ministries, such as the Ministries of Education, Culture, Justice, or Construction.

Local governments (on each level: communal, district, and voivodship) pay special attention to family issues. At the communal level, social assistance centers are set up that provide means-tested benefits for families and organize social work to assist them in overcoming emergency situations. ${ }^{80}$ The centers provide help following a thorough analysis of the economic and social circumstances of the family with the aim of making beneficiaries independent.

At the district level, family support centers are created. Their task is, inter alia, to organize and support foster families and set up and operate care and educational centers. ${ }^{81}$ The district government is also responsible for founding committees whose task is to address the specific needs of families with children with disabilities. ${ }^{82}$

79 Act of 11 February 2016, on State Assistance in Child Rearing, ct. Journal of Laws of 2019, Item $2,407$.

80 Act of 24 March 2004 on Welfare, ct. Journal of Laws of 2020, Item 1,876.

81 Act of 9 June 2011 on Supporting Family and Foster Care, ct. Journal of Laws of 2020, Item 821 as amended.

82 Act of 27 August 1997, on Social and Vocational Rehabilitation and Employment of the Disabled, ct. Journal of Laws of 2021, Item 573. 
The voivodship (province) government is charged with the task of organizing regional welfare centers.

\subsection{Family courts}

The primary institution tasked with resolving family legal problems is the family court, established in Poland at the end of the 1970s. ${ }^{83}$ Family courts are the family and juvenile divisions of regional courts and some district courts. It is no longer obligatory for district courts to have a family division, but those existing have rightly not been shut down.

Regional family courts handle cases in matters related to the FGC, with the exception of the most complex and difficult cases, such as cases of divorce and separation. These regional courts are the courts of first instance. Family courts also adjudicate when claims are made under the acts on juvenile justice, ${ }^{84}$ on rearing in sobriety and combatting alcoholism, ${ }^{85}$ on the protection of mental health, ${ }^{86}$ and on supporting the family and the foster care system, ${ }^{87}$ and others.

The creation of the family courts was promoted by the following ideas:

1. to concentrate under one judge all family cases that go to court from one particular region (city, borough, or municipality); $; 8$

2. accord cases be heard by judges who possess both a high level of legal competence and a thorough understanding of psychological, pedagogical, or social issues indispensable for a firm grasp of the specific nature of the cases under consideration. These judges should be able to cooperate with people and institutions that deal with family issues, including agencies of the social welfare system, non-governmental organizations, and the prosecutor's office; ${ }^{89}$ and

3. to provide judges with support from a network of expert institutions.

The designed model of the family court system has, however, never been implemented, leaving scholars and specialists to debate ways to improve its current performance.

Probation offices are an auxiliary agency to family courts. These offices are divided into adult probation officers-who deal with people released from prison and demoralized minors ${ }^{90}$ - and family probation officers. All operate outside court, performing educational, rehabilitation, diagnostic, preventive, and control tasks; in all their actions they execute court decisions.

83 Zedler, 1984, pp. 7-46.

84 Act of 26 October 1982, ct. Journal of Laws of 2018, Item 969

85 Act of 26 October 1982, ct. Journal of Laws of 2012, Item 1,356 as amended.

86 Act of 19 August 1994, ct. Journal of Laws of 2020, Item 685.

87 Act of 9 June 2011, ct. Journal of Laws of 2020, Item 821 as amended.

88 Arczewska, 2009, pp. 64-127; Słyk, 2019, pp. 54-65.

89 Czech, 2011, pp. 15-18.

90 Act of 27 July 2001 on Probation Officers; ct. Journal of Laws of 2020, Item 167. 


\subsection{Combatting domestic violence}

In Poland the legal basis for combating domestic violence is laid out in the Act of July 29, 2005. ${ }^{91}$ From the point of view of the legal protection of the family, what is of interest in here is the establishment of interdisciplinary teams at the communal level that are charged with performing comprehensive analyses of domestic violence and developing methods to combat it. The teams are composed of representatives of social welfare and communal commissions that work to solve alcoholrelated problems, the police, educational institutions, healthcare organizations, nongovernmental bodies, and probation officers. In addition to developing anti-violence programs geared toward supporting the victims of domestic violence, the teams implement agenda laid out in communal programs of prevention of domestic violence and protection of victims of such violence. The teams establish a special task force to resolve and combat problems of violence in individual cases. The task force assesses a particular situation, develops and implements an assistance plan tailored to suit the particular case, monitors the situation, and documents the taken actions.

\subsection{Miscellaneous}

Poland has many other institutions and institutional measures aimed at the legal protection of the family, but the scope of this study is limited to listing few of them, indicating key legal acts and highlighting some of the relevant literature.

The prevalence of alcoholism means that an important part of family policy is resolving alcohol-related problems, which entails both prevention and mitigation of the effects. To that end The State Agency for Resolving Alcohol Problems and communal committees were established. ${ }^{92}$

Another acute and widespread problem is parental ineptitude. In 2011, a new position to address this issue was created: the family assistant. ${ }^{93}$ Family assistants operate at the level of local government. If a family refuses to accept the assistant, then he or she may be assigned to the family under a family court injunction limiting parental authority (Art. $109 \S 2$ (1) of FGC).

An important factor in family protection that requires a separate, extensive discussion is that of the various social benefits targeted at families. In recent years the catalog of such benefits has been expanded and their significance in household budgets has also increased. The most important of them is the so-called $500+$ benefit paid to parents monthly for each child under the age of 18 . Other means-tested benefits and entitlements include a family allowance; supplements to family allowance for, among other things, childbirth, single parents, childcare as part of maternity

91 Ct. Journal of Laws of 2020, Item 218.

92 Act of 26 November 1982, ct. Journal of Laws of 2016, Item 487 as amended, on Upbringing/Education in Sobriety and Counteracting Alcoholism.

93 Krasiejko, 2011. 
leave, large families, education and rehabilitation of a child with disabilities; ${ }^{94}$ cash from social insurance in the event of sickness and maternity, including maternity allowance and care allowance; ${ }^{95}$ and benefits for people who cannot make ends meet due to the delinquency of their debtors in paying maintenance (see 3.5.5). ${ }^{96}$

It should be also mentioned that an important obstacle for women in their professional life is the shortage of available nurseries and kindergartens. Psychiatric care for children is likewise deficient due to lack of medical personnel and investment in infrastructure.

\section{Current dilemmas over legal protection of marriage and the family}

\subsection{Dispute over the attitude of the state towards the family}

There is a general debate in Poland as to whether and to what extent the state should intervene in the family in order to achieve an appropriate balance between the autonomy of the family in relation to the state and the admissibility of a state to interfere in the life of the family. This issue touches on the constitutional principles of family autonomy and the primacy of parents in child-rearing (Articles 47 and 48(1) of The Constitution), which are primarily understood as autonomy and primacy over state institutions that govern education, health care, social assistance, and the administration of justice, among others. ${ }^{97}$

The Constitution asserts that the state may not remain passive towards the family but should protect (Art. 18) and support it by implementing social policy in favor of the family or intervene, if necessary, especially for the protection of children (Articles 48 (2) and 72 (1).

\subsubsection{State and divorce}

In the debate regarding whether a divorce should be granted at the request of the spouses or whether it may be granted only after the conditions set out in law are met, ${ }^{98}$ the position of the Polish legislation (Art. 56 FGC) differs from the measures adopted in most European countries, in which divorce by mutual consent dominates

94 Act of 28 November 2003 on Family Allowance, ct. Journal of Laws of 2020, Item 111.

95 Act of 25 June 1999 on the Money Benefits from Social Insurance in Case of Illness and Maternity, ct. Journal of Laws of 2020, Item 870.

96 Act of 7 September 2007 on Assistance to Persons Entitled to Alimony ct. Journal of Laws of 2020, Item 808.

97 Banaszak, 2009, pp. 244-253; Smyczyński, 2012, pp. 14-17.

98 Mazurkiewicz, 2012; Andrzejewski, 2016. 
and no court proceedings are involved. Instead, an administrative authority or a notary may dissolve a marriage. These measures perceive marriage in individualistic terms, ignoring the communitarian ${ }^{99}$ aspect of marriage, and thus do not treat the legal aspects of marriage (the contract, its function, the possible reasons for dissolution) seriously.

In Poland, a divorce may be granted only in court on the grounds of a complete and permanent breakdown of the marriage and as long as the divorce does not diverge from the principles of social coexistence, especially concerning the good of minor children (Art. $56 \S 1$ and $\$ 2$ FGC). Divorce is also inadmissible if the action is brought by the spouse who is solely guilty of the circumstances causing the breakdown of the marriage unless the other spouse agrees to the divorce, or the refusal to consent is considered contradictory to the principles of social coexistence (Art. 56 §3 FGC ). ${ }^{100}$ Evidence should therefore always be collected and presented before the court in order to verify the grounds for divorce.

On the other hand, at the unanimous request of both parties, the court may grant a no-fault divorce (Art. 57 FGC) and refrain from adjudicating on access to children (Art. $58 \S 2$ FGC). The divorcing spouses may also prepare a child custody proposal (Art. 58 \& 2 FGC). The court will accept the agreement if its provisions do not contradict the best interests of the child. ${ }^{101}$

\subsubsection{Pregnant women and alcohol consumption}

In the public debate in Poland, it has been put forward that a pregnant woman who consumes alcohol should undergo treatment for drug addiction or at least detoxification in order to save her child from the onset of damage in the fetal phase of life referred to as FAS syndrome (fetal alcohol syndrome ${ }^{102}$ ). ${ }^{103}$ Indeed, there is a clear cause-and-effect relationship between the development of FAS syndrome and the consumption of alcohol by a pregnant woman.

\subsubsection{The state and so-called reproductive rights}

In this debate the basic question raised is whether adults have the right to have children, which is correlated with the state's obligation to ensure a child to anyone who requests it, be it through adoption or artificial methods of procreation. ${ }^{104}$ This triggers the consequent dilemma of whether the use of all technology in the field of artificial procreation is morally permissible. ${ }^{105}$ At the other end of the spectrum,

99 Terlikowski, 2006, p. 11-22; Rymsza, 2009, pp. 57-69.

100 Stojanowska, 2009, pp. 562-666; Olejniczak, 1980; Gajda 2020, pp. 482-493.

101 Sokołowski, 1997, pp. 96-101; Gajda 2020, pp. 500-503.

102 Banach and Matejek, 2016.

103 Bernfeld et al., 2019.

104 Bagan-Kurluta, 2018; Śledzińska-Simon, 2009; Łączkowska, 2005.

105 Stelmach et al., 2010; Varaut, 1996; 
it is more often claimed that adults have the right not to have children. The consequence of the latter is the state's obligation to guarantee abortion at the request of a pregnant woman, regardless of the circumstances. The polar opposite opinion to this statement posits that the fetus has the right to protection. ${ }^{106}$

In regard to so-called "reproductive rights," a heated dispute rages in Poland over the admissibility of abortion (see 3.5.3). Meanwhile, the use of technology supporting procreation is regulated by the Act of 2015 on the treatment of infertility, ${ }^{107}$ which introduced the prospect of performing in vitro procedures that are reimbursed by some local governments. So-called "surrogate motherhood"108 and ensuing contracts remain invalid (according to Art. $58 \mathrm{CC}$ ).

In the context of reproductive rights, there are no postulates for allowing homosexual couples to adopt children. The legal doctrine in Poland is dominated by a critical approach to this idea. ${ }^{109}$

In recent years the subjects of both the jurisprudence of administrative courts and disputes in the Polish doctrine have been issues centered on a demand to enter a child's filiation in the Polish register of marital status from same-sex parents. The Supreme Administrative Court in its resolution of 212.2019. II OPS 1/19 did not allow foreign birth certificates of children with same-sex parents to be acknowledged in Poland. ${ }^{110}$

\subsubsection{Dispute over the concept of marriage}

The focal point in this dispute is the admissibility of same-sex couples entering into marriage. ${ }^{111}$ The same issue arises regarding mentally ill persons whose mental impairment renders it impossible for them to fulfill marital and family obligations. ${ }^{112}$ In the case of mentally ill persons, the CT found Art. 12 FGC in compliance with the Constitution. This article banned marriage in the case of persons whose mental impairment would threaten the marriage and well-being of any offspring (see 3.5.1).

As already mentioned, under Polish law, marriage is a union of a man and a woman (Art. 18 of the Constitution) and it is performed on the basis of a consistent declaration made by them, either before the head of the Civil Registry Office or before a competent clergyman (a religious form with consequences for secular law; see Art. 1§2 FGC). Homosexual couples are allowed to neither marry nor register

106 Mazurkiewicz and Mysiak (eds.), 2017.

107 Journal of Laws of 2015, Item 1,087.

108 Haberko, 2016; Telusiewicz, 2019, pp. 497-508.

109 Sokołowski, 2013, pp.103-116; Gajda 2013, pp. 117-126.

110 Mostowik, 2019, pp. 3-29; Zachariasiewicz, 2019, pp. 143-170.

111 Łączkowska-Porawska, 2019; Łączkowska, 2013, pp. 171-208; Mączyński, 2013, pp. 83-102; Smyczyński 2013, pp. 71-82; Pawliczak, 2013; Łętowska and Woleński, 2013; Banaszkiewicz, 2004; Hartwich, 2011.

112 Judgement of the CT of 22 November 2015, sig. K13/15; Kmieciak, 2018. 
their partnerships. Over the last two decades, several bills aimed at legitimizing such unions have been rejected in the Polish Parliament (see 6.5).

\subsection{Concept of the family}

In the above section, the family was discussed in the context of social policy (see 4.1) and in provisions of The Constitution (Arts. 18 and 71) (see 3.1). This section will discuss the concept of marriage on the basis of ordinary acts.

The Family and Guardianship Code regulates the functioning of the family, which is understood as a marriage and a two-generation family (in the language of sociology, a nuclear family). ${ }^{113}$ Only the provisions on the maintenance obligation apply to all relatives in lineal descent, and kin in the stepfather/stepmother-stepchildren relations may be included as eligible (Art. $113^{6}$, Art. 129, and Art. 144 FGC).

The provisions of inheritance law (Art. 931-941 CC) include the spouse, descendants, parents, siblings and their descendants, grandparents, and their descendants, and in exceptional circumstances, stepchildren as those legally eligible to inherit the property of the deceased.

The provisions of administration law likewise define the family by indicating specific ties between individual family members. In the Act on Social Assistance, ${ }^{114}$ for instance, the ties are economic as the family is defined as persons forming a common household. The Act on Pensions and Old-Age Pensions from the Social Insurance Fund ${ }^{115}$ indicates that the death pension given to the relatives of the insured deceased will be granted to, among others, the deceased's own children, his or her stepchildren, adopted children, other children raised and maintained in the household before they come of age, grandchildren, siblings, a spouse (widow or widower), as well as parents (including stepmother, stepfather or adopters) (Art. 67). The family circle exempt from tax under the Act on Inheritance and Donation Taxes ${ }^{116}$ includes the husband, wife, descendants, ascendants, as well as stepchildren, siblings, stepfather, and stepmother (Sons-in-law, daughters-in-law and in-laws are excluded.).

Differences in the definition of the concept of family are justified by the purpose of different legal acts. The prevailing position in the Polish doctrine is that there is no need to create a legal definition of the family that would apply to all regulations regarding the functioning of this social group.

\subsection{Cohabitation}

In Polish legal language-that used in the Polish doctrine-the term "cohabitation" refers to a man and a woman living in a stable relationship. Similarly to 
married life described in Art. 23 FGC, this relationship is realized in economic, spiritual, and sexual spheres. In more recent literature, cohabitation is sometimes referred to as a civil partnership, which may be confusing in the context of same-sex relationships.

Cohabitation (also referred as concubinage), provided that it produces children, is a family in the sociological sense and thus the recipient of social policy (Art. 18 of The Constitution). Cohabitants may receive social assistance benefits since in the doctrine a family consists of persons running a common household, but they acquire no right to a dependent's pension.

As an informal relationship, concubinage is subject to no registration. Cohabitation creates no formal grounds for using a partner's apartment. Likewise, provisions in the FGC on property and matrimonial regimes are inapplicable to cohabitants. Issues of settlements after the termination of concubinage are resolved on the basis of the CC provisions. ${ }^{117}$

The presumption that a child born to a cohabitant is the child of a cohabitant does not apply; filiation of a child is determined by recognition of paternity. For filiation to be recognized, a man must submit a declaration declaring that he is the child's father, which must then be confirmed by the child's mother (Art. 73 §1 FGC).

Cohabitants have joint custody over their child and their parental rights do not generally differ from those of married parents. Cohabitants may not adopt a child jointly as such adoption is permitted only to spouses (Art. $115 \S 1$ FGC). In practice, it is also impossible to adopt a partner's child as this would lead to the termination of the legal relationship between the child and his/her parent.

In the event of the death of a cohabitant who is the tenant of a flat, his or her partner may enter into a tenancy relationship as the living partner of the tenant (Art. $691 \S 1$ of CC).

Cohabitants do not inherit by law; nor are they entitled to a reserved share (Art. 931-941 of CC and Art. 991 of CC). They are also unrelated in the eyes of tax law. In criminal, civil, or administrative proceedings, cohabitants enjoy the status of next of kin, which affords them the right to refuse to testify, for instance, in a criminal trial against a partner. Unlike homosexuals, cohabitants have yet not formed nongovernmental or political organizations and have submitted no legislative demands to give a legal framework for their way of life.

\subsection{Protection of same-sex relationships}

Homosexuals living in long-term relationships are referred to in the literature as partnerships like those cohabiting. In Poland, legislative action was taken to legitimize such relationships (note the emphasis on legitimize rather than legalize, since homosexuality has never been illegal in Poland (in fact in Poland homosexual acts have never been penalized). The attempts found no support, however, in the Polish 
Parliament. As a consequence, the relationships between homosexuals in long-term relationships are not registered.

Until now, bills submitted to Parliament to regulate the functioning of homosexual couples have aimed at making changes to define the status of their relationships as marriage, i.e., to grant same-sex couples the status of married couples under Polish family law. In the literature, apart from an open criticism of the idea of institutionalizing same-sex relationships and their approval, we also find a compromise solution resembling the law on the social solidarity pact (PACS) in operation in France, which provides for the registration of a civil partnership and the regulation of economic issues such as taxation, loans, inheritance, and lease. Such a model would require no amendment to The Constitution, in which marriage was defined as a union between a man and a woman, as the registered same-sex relationship would not be a marriage.

On many points, the legal status of same-sex unions resembles that of cohabitants. Just like cohabitants, they may take advantage of social welfare benefits, assume the rights of a deceased partner who is a tenant of a flat, ${ }^{118}$ and exercise the right to refuse to testify as a person close to the defendant in a court case. On the other hand, the partner, like a cohabitant, may not exercise the right to use accommodation owned by a partner (Art. $28^{1} \mathrm{FGC}$ ); nor do the provisions on matrimonial property regimes (Art. 31-54 FGC) apply to them. The settlements between them may, however, be affected inter alia by provisions on unjust enrichment or on the fulfilment of a common economic goal in the form of a civil partnership. ${ }^{119}$

Partners do not inherit their deceased partner's property under the provisions of the law, but they may appoint any person in their will as the beneficiary. They are not entitled to a legitimate portion. In addition, partners may not adopt children together.

In relation to the partner's child, a person in a permanent same-sex relationship does not enjoy the status of guardian (as long as a child's parents exercise parental responsibility over him/her, it is formally unacceptable), nor any other formal authorization.

Under medical law, homosexuals have the same status as spouses, both in terms of the right to information regarding a partner's health and hospital visits. The rights can be exercised only by the persons indicated by the sick. Without the consent of the patient, the doctor may only provide information to the statutory representative, i.e., the parent or legal guardian.

The admissibility in Poland of homosexual marriage certificates obtained abroad is in dispute. On the one hand, the literature emphasizes that the legal status in Poland (Art. 18 of The Constitution) prevents transcription; on the other hand, the jurisprudence of the European Court of Human Rights and the standard of legal protection of such relationships designated therein are highlighted. ${ }^{120}$ 
Homosexuals may avail themselves of the right to create social organizations benefiting their community and to present their views in the media (they own magazines and websites) or via social activism in the form of public gatherings.

\section{Marriage and family: Crisis prevention and management}

Public opinion and The Constitution both place great value on marriage and the family. It is therefore necessary to indicate the ways in which they may be supported and helped in preventing projected crises.

The guardianship court and other public authorities are obliged to "provide assistance to parents if it is necessary for the proper exercise of parental responsibility" (Art. $100 \S 1$ FGC). Difficulties in this regard should not engender criticism but rather concerted efforts to support them.

One form of family support in crisis is therapy. Motivation to participate in psychological therapy should come from the affected person or family, but therapy may also be necessitated by an obligation imposed on a parent whose behavior constitutes a threat to the child's well-being. A parent whose behavior poses a threat to a child's good may be required to seek psychological therapy. Such behavior may be the basis for a decision issued by the family court to limit parental authority (Art. 109 §2 (1) FGC).

Two legal institutions may be used in divorce or legal separation proceedings to encourage the divorcing spouses to talk and reach a compromise. The first is mediation, a process regulated by Art. $183^{1}-186$ of the Civil Procedure Code ${ }^{121}$ that aims to help spouses reach an agreement in all matters to be resolved in the divorce decree. Mediation is voluntary, so if a spouse refuses to participate or displays disruptive behavior, this cannot be considered by the court when reaching a judgment. Mediation is also used in custody proceedings concerning parental responsibility. The second institution of divorce law is the "parental agreement, which lays out the manner of exercising parental authority and maintaining contact with the child after the divorce" (Art. 58 § FGC). The court takes these measures into account if it finds that it is in the best interests of the child. A lack of agreement means that the burden of decision falls on the court.

Separation is an institution that is conciliatory in character and intention. It arose as a response to the proposal to keep marriage permanent and is thus addressed to people who conscientiously take marriage, even in terms of secular law, to be an indissoluble union. Legal separation allows spouses to settle issues related to their failed marriage, which are typically settled in the divorce decree, but in this case without dissolving the marriage bond. In a separation, the legal status of 
a marriage continues in spite of a complete breakdown of the marriage in all its aspects (Art. $61^{1} \S 1$ FGC).

\section{Selected aspects of the legal status of child}

This section will discuss only some of the issues regarding a child's legal status as several problems concerning children have already been discussed in 2.1, 2.3.4, and 3.5.3.

\subsection{Subjectivity and identity of the child}

The subjectivity and dignity of a child are guaranteed by a constitutional norm (Art. 72(1) of The Constitution), standards set out in the UNCRC, and a number of provisions of the FGC, particularly those regarding parental authority exercised over children (Art. 87 and Arts. 93-105). The same documents emphasize the specific character of the legal protection of a child, stemming from the fact that the child grows up in a family, and parents have primacy in his/her upbringing (Art. 48 of The Constitution, Arts. 5 and 18 of the UNCRC, and Arts. 87-112 of the FGC). In Poland, the child's legal situation is perceived through the prism of the parental authority exercised by his/her parents ${ }^{122}$ and the implementation of the child's rights is mediated in the family in which he/she is raised. If what parents do is to be regarded as the exercise of parental responsibility, it must be done in the best interests of the child and with the child's well-being in mind. If the parents abuse their superior position in relation to a child, then what they do is not exercising parental authority and it may constitute grounds for depriving them of that right (Art. $111 \S 1$ FGC). Parents may not use corporal punishment on their child (Art. 96 FGC).

One of the most important issues related to the subjectivity of a child and his/her identity is shaping his/her worldview. ${ }^{123}$ When bringing up a child within a given religion or in the spirit of agnosticism or atheism, parents should take into account the child's stage of development and his/her reasonable expectations (Arts. 48, 53(3), and 72(1) of The Constitution). In this case, as well as in other matters concerning the child that fall within the ambit of the parents as part of their parental authority, parents should know the child's opinions and, if possible, take them into account (Art. 95 \& 4 FGC). ${ }^{124}$ A case in point is the decision to opt out or enroll a child in religious classes, which lies in parents' competence. 
Polish law establishes several ages at which the scope of the child's rights increases, while simultaneously stricter sanctions are imposed. At the age of 13 , for example, a child achieves limited legal capacity (Art. 15 CC). On the grounds of the Act on Juvenile Delinquency Proceedings, the child may then be liable not only for demoralization but also for a specific punishable act (Art. 1§1). When turning 15, a minor who commits a particularly serious crime may be held accountable by a criminal court as an adult (Art. $10 \S 1$ the $\mathrm{CrC}$ ). The child may also sign an employment contract. At the age of 16, minors, irrespective of their parents or guardians, have the right to consent to hospitalization or medical treatment, and at the age of 17 the child is responsible under criminal law as an adult.

Further evidence that a child is treated as a legal subject is the fact that children have the right to participate in the legal procedures that concern them. Article 72(3) of The Constitution, in accordance with Art. 12 of the UNCRC, mentions the obligation of public authorities (including courts and administrative bodies) and those responsible for the child, e.g., parents or teachers, to "hear and, as far as possible, take into account the child's opinion."

In court proceedings, a child's opinion is expressed and formulated during psychological tests in the form of counselling that takes place outside courtroom (Art. $216^{1}$ Civil Procedural Code). The Polish doctrine postulates that during this counselling a lawyer be assisted by a psychologist. Also, new regulations (Arts. 991-993 FGC) on providing tutelage of a child in family matters warrant positive opinion.

\subsection{Forms of parental control}

The state may question the autonomy of the family and the primacy of parents in bringing up a child: under the circumstances specified in Arts. 109, 110, and 111 in the FGC, it may intervene in parental authority. ${ }^{125}$ The main aim of the constraint of parental authority would be to correct the situation in the family that threatens the good of the child; therefore, the constraint should be temporary. Depending on the scale of the problems, the court may apply different orders: cooperation with a family assistant, enrollment of the child in a day care facility, supervision by a probation officer, and even placing the child with a foster family or in an institution. The justification for such orders may entail diverse, sometimes drastic circumstances, but all these suggest that there are arguments to protect a family by affording it support.

If there is a short-term obstacle in the exercise of parental authority, the court may temporarily suspend it (Art. 110 FGC). However, the court is obliged to remove parental authority from those parents who grossly neglect their child, abuse their parental authority (in practice, if they commit a criminal offense against the child), or if there is a permanent obstacle to exercising the authority (Art. $111 \S 1$ FGC). Parents may also be deprived of their parental authority if they show no interest in the child once he/she is placed in foster care (Art. $111 \S 1 \mathrm{a}$ FGC). 
Parental authority also expires if a parent becomes incapacitated. When a child has been completely incapacitated, then the parents are subject to the same restrictions as the legal guardian (the court supervises their actions in relation to the child).

The exercise of parental responsibility entails a number of parental obligations specified in acts of administrative law. Parents are responsible, for instance, to ensure that their children study and attend all levels of compulsory education. They must also ensure a child receives all mandatory vaccinations or hospital treatment. If parents fail to fulfill these obligations, administrative bodies may compel them by means of a fine. The bodies may also inform the family court of the delinquency of the parents.

\subsection{Adoption and foster care}

Only minors may be adopted and for the sole purpose of his/her good. An adoptive parent needs to be suitably older than the adopted child and he or she must possess the personal attributes to cope with the obligations of child-rearing. Such suitability is ascertained by adoption centers that issue a certificate of the completion of relevant training and an opinion on whether the candidate is qualified to adopt a child (Art. $114^{1} \mathrm{FGC}$ ). The rules governing the way adoption centers conduct the qualification procedure of persons intending to adopt a child and the manner in which a register of children prepared for adoption must be maintained, are laid out in the provisions of the Act of June 11, 2011 on Supporting the Family and the Foster Care System.

A child is qualified for adoption if his or her parents fail to exercise parental authority over him/her because they are dead, unknown, have been relieved of their parental authority or have consented to the adoption of their child. Upon consenting to relinquish their parental rights, parents may not indicate candidates for the adoptive parents other than close members of the child's parents' family (Art. $119^{1 \mathrm{a}} \mathrm{FGC}$ ).

Polish law permits adult adoptees to know their biological origins. The court may allow them access to their complete birth certificate, which would contain information about the adoption (the Act on Civil Status Records). ${ }^{126}$ In legal transactions, only abbreviated copies of the original birth certificate are used and these list the adoptive parents as parents.

As a general rule, married couples are preferred as adoptive parents, but it is also possible for a single person to adopt. Joint adoption of a child by cohabitants is not permitted. A full adoption modifies the child's legal status, making the adoptive parents his/her parents, meaning that they exercise parental authority over the child, and enabling parties in the adoption relationship to inherit and provide maintenance. Under specific circumstances, this adoption can be dissolved (Art. 125 
FGC). On the other hand, a "blanket" adoption, i.e., the one adjudicated in the event of the parents' death or their consent to adopt the child without an indication of the adopter (blanket authorization), is additionally unbreakable (Art. $125^{1} \S 1$ FGC).

Adoption involving transfer of the child abroad (so-called foreign adoption) ${ }^{127}$ is permitted only if it has proved impossible to find a substitute family for the child in Poland. (This applies not only to adoption, but also to placing a child in a foster home.)

In recent years adoption has become less popular due to the availability of artificial forms of procreation that allow almost all parents to experience parenthood from conception. Another important reason for this decline in popularity is the ease with which adoptees can learn about their own roots, which encourages them to build relationships with their biological family.

Foster care is regulated in Arts. $112^{1}-112^{8}$ of the FGC and in the Act on Family Assistance and Foster Care and is provided in the form of a family (foster families) or institutional (child care homes) environment. It replaces the care provided by parents when they are unable to do so. The strategic goal of placing a child in foster care is to bring him or her back to the family after he or she has received support, and new conditions conducive for reintegration are created. ${ }^{128}$ If this goal is not achieved, parental authority may be removed from the biological parents and the child may be transferred for adoption. In practice, many charges remain in foster care for long periods of time due to the inability to either return to their parents or be put up for adoption for formal reasons. Other reasons for an extensive stay in foster care are that a child does not consent to adoption or there are no suitable adopters available.

The formal basis for placing a child in foster care is a court order. As a rule, it may limit parental authority (Art.109 § 2(5) FGC), suspend it (Art. 110 \$1 FGC), and, on rare occasions, remove it (Art. $111 \S 1$ FGC ). During the child's time in foster care, remedial actions are taken towards the biological parents (Art. 109 § 4 FGC). If these actions prove ineffective, parents may eventually be stripped of their parental authority (Art. $111 \S 1$ a FGC).

Foster families who are the child's relatives predominate. The rest comprise professional foster families (including emergency foster care), therapeutic foster care (for sick and disabled children), social rehabilitation foster care (for demoralized youth), and foster care for adolescent mothers.

Foster care to function properly requires cooperation between the family court, family foster care organizations, municipal and regional social welfare structures, probation officers, and many others. However, no appropriate forms of cooperation have thus far been developed, which means that the end result is unsatisfactory in terms of meeting children's needs. ${ }^{129}$

127 Bagan-Kurlata, 2009; Holewińska-Łapińska, 2011.

128 Nitecki, 2016.

129 Arczewska, 2009; Andrzejewski, 2003. 
In foster families, foster parents are commonly observed to consider the foster child as their own child (quasi-adoptive motivation), not as a child who has a family to which he or she should return. This causes problems in contacts between parents and their children and hampers family integration. 


\section{Bibliography}

ADAMSKI, F. (1987) Rodzina między sacrum a profanum. Poznań: Pallottinum.

ADAMSKI, F. (2002) Rodzina. Wymiar społeczno-kulturowy. Kraków: Wydawnictwo UJ.

ANDRZEJEWSKI, M. (2003) Ochrona praw dziecka $w$ rodzinie dysfunkcyjnej (dziecko-rodzinapaństwo). Kraków: Zakamycze.

ANDRZEJEWSKI, M. (2012) 'Prawa dziecka - rozważania o sensie idei i jej dewaluacji' in Andrzejewski, M. (ed.) (2012a) Prawa dziecka. Konteksty prawne i pedagogiczne. Poznań: Wydawnictwo Naukowe UAM.

ANDRZEJEWSKI, M. (ed.) (2013) Związki partnerskie - debata o projektowanych rozwiązaniach prawnych. Toruń: TNOiK.

ANDRZEJEWSKI, M. (2015) 'Obowiązek alimentacyjny a uprawnienia doświadczeń socjalnych (w świetle wyroku TK (K 12/12) dotyczącego świadczeń dla wychowanków rodzin zastępczych)' in Nazar M. (ed.) Prawo cywilne - stanowienie, wykładnia i stosowanie. Księga pamiątkowa dla uczczenia setnej rocznicy urodzin Profesora Jerzego Ignatowicza. Lublin: Wydawnictwo UMCS.

ANDRZEJEWSKI, M. (2016) 'O potrzebie reformy prawa rozwodowego', Studia Prawnicze, no. 3 ARCZEWSKA, M. (2009) Role społeczne sędziów rodzinnych. Warszawa: Wydawnictwo UW.

BAgAn-Kurluta, K. (2009) Przysposobienie międzynarodowe dzieci. Białystok: Temida2.

BAGAN-KuRLUTA, K. (2018) 'Konsekwencje rozwoju medycyny dla prawa prokreacyjnego. Rozważania nad prawem polskim i izraelskim', Prawo i Medycyna, 2018/1.

BALCERZAK-PARADOWSKA, B. (ed.) (1999) Sytuacja dzieci w Polsce $w$ okresie przemian. Warszawa: IPiPS.

BALCERZAK-PARADOWSKA, B. (2009) 'Dziecko w polityce rodzinnej. Ocena działań dotychczasowych. Wzorce z innych krajów', Polityka Społeczna, 2009/9.

BANACH, M., MATEJEK, J. (2016) W trosce o zdrowie dziecka i twoje: Płodowy Zespół Alkoholowy (FAS). $2^{\text {nd }}$ edn. Kraków: Scriptum.

BAnAszaK, B. (2009) Konstytucja Rzeczpospolitej Polskiej. Komentarz. Warszawa: C.H. Beck.

BANASZKIEWICZ, B. (2004) 'Problem konstytucyjnej oceny instytucjonalizacji związków homoseksualnych', Kwartalnik Prawa Prywatnego, 2004/2.

BeCKer, PestKA, D. (2012) 'Rodzina w obliczu emigracji zarobkowej', Colloquium WNHiS $A M W$, no. 1.

BERnFEld, B. MAZURKIEWICZ, J., ZAPOROWSKA, M. AND ZAPOROWSKA, Z. (2019) Czy prawo musi być bezradne. Prawne aspekty przeciwdziałania poalkoholowym uszkodzeniom płodu?. Warszawa: IWS.

BIAŁECKI, M. (2012) Mediacja w postępowaniu cywilnym. Warszawa: Wolters Kluwer.

Bовко, А. (2021) 'Co nam zostało z idei praw człowieka', PlusMinus. 10-11.04.

BoczeK, M. (2017) 'Obowiązek alimentacyjny — przymus państwowy czy powinność moralna?' in Sztychmiller, M., Krzywkowska, J. and Paszkowski M. (eds.) Problemy mał̇̇eństwa $i$ rodziny $w$ prawodawstwie polskim, międzynarodowym $i$ kanonicznym. Olsztyn: UWM.

Borkowicz, J. (2021) 'Ideologia i ludzie', PlusMinus. 10-11.04.

CHERIN, J. (2004) 'The deinstitutionalization of American Marriage', Journal of Marriage and Family, 66(4), pp. 848-861; https://doi.org/10.1111/j.0022-2445.2004.00058.x.

Cierniak-Piotrowska, M., FrAnECKA, A., StAŃCZAK, J., STElmaCh, K. AND ZnAJEWSKA, A. (eds.) (2019) Sytuacja demograficzna Polski do 2018 r. Tworzenie i rozpad rodzin, Analizy Statystyczne. Warszawa: GUS. 
Cornides J. (2010) 'Prawo Naturalne i Nie-Naturalne', Międzynarodowy Przegląd Polityczny, 26(2).

CuBE, G. (2013) Globalna rewolucja seksualna. Likwidacja wolności w imię wolności. $2^{\text {nd }}$ edn. Kraków: Homo Dei.

CYWIŃSKI, B. (1990) Ogniem próbowane. Warszawa: Papieski Instytut Studiów Kościelnych.

CZECH, B. (2011) 'Z rozważań nad postępowaniem i orzecznictwem w sprawach rodzinnych (niezawisłość sędziowska, sprawy o rozwód, sprawy opiekuńcze małoletnich, sędziowie rodzinni, dobro dziecka, opinie biegłych)', Rodzina i Prawo, no. 20.

CzubKowskA, S. AND Klinger, K. (2010) 'Bieda utrwalona zasiłkiem’, Dziennik Gazeta Prawna, 20.04.

DANILEWICZ, W. (2010) Rodzina ponad granicami. Białystok: Trans Humana.

DOMAŃSKI, H. (2002) Ubóstwo $w$ społeczeństwach postkomunistycznych. Warszawa: ISP.

DŁUgoszeWsKA, I. (2012) Przesłanki oraz skutki ograniczenia i pozbawienia władzy rodzicielskiej. Warszawa: LexisNexis.

DYCZEWSKI, L. (1994) Rodzina, społeczeństwo, państwo. Lublin: TN KUL.

Dylus, A. (1995) 'Zasada pomocniczości a integracja Europy', Państwo i Prawo, 1995/5.

FreEMAN, M. (2002) Prawa człowieka. Warszawa: Sic.

GAJDA, J., (2009) 'Zawarcie małżeństwa' in Smyczyński T. (ed.).

GAJDA, J, (2013) 'Adopcja przez pary homoseksualne. Aspekty prawne' in Andrzejewski, M. (ed.)

GAJDA, J. (2020) in Pietrzykowski, K. (ed.).

GIUBILINI, A. AND MinERVA, F. (2013) 'After-birth abortion: why should the baby live?' Journal of Medical Ethics, 39(5), pp. 261-263; https://doi.org/10.1136/medethics-2011-100411.

GLYNN, K.N. (2013) 'Always a bridesmaid never a bride: examining the deinstitutionalization of marriage and the modern-day spinster', Boise State University. Available at: https://bit. ly/2ZlzMQP (Accessed: 1 May 2021).

GolinowsKA, S. (1994) Polityka społeczna państwa $w$ gospodarce rynkowej. Studium ekonomiczne. Warszawa: PWN.

GrabARCZYK, A. (2019) 'Prawo do przeniesienia do rejestru stanu cywilnego małżeństwa jednopłciowego na tle orzecznictwa ETPC w Strasburgu', Studenckie Zeszyty Naukowe, 2019/40.

HABERKO, J. (2016) Ustawa o leczeniu niepłodności. Komentarz. Warszawa: Wolters Kluwer.

HABERKO, J. (2010) Cywilnoprawna ochrona dziecka poczętego a stosowanie procedur medycznych. Warszawa: Wolters Kluwer.

HARTWICH, F. (2011) Związki partnerskie. Aspekty prawne. Warszawa: LexisNexis.

HOLEWIŃSKA-ŁAPIŃSKA, E. (2011) 'Przysposobienie', in: Smyczyński T. (ed.).

IGNATOWICZ, J. AND NAZAR, M. (2016) Prawo rodzinne. $5^{\text {th }}$ edn. Warszawa: Wolters Kluwer.

IZDEBSKI, Z., NIEMIEC, T. AND WĄŻ, K. (2011), (Zbyt)młodzi rodzice. Warszawa: Trio.

JARos, P.J. (2015) Prawo dziecka do rodziców (odpowiedzialności rodzicielskiej) $w$ kontekście polskich zobowiązań międzynarodowych. Warszawa: UKSW.

KAlisZ, A. AND ZIENKIEWICZ, A. (2014) Mediacja sądowa i pozasądowa. Zarys wykładu. Warszawa: Wolters Kluwer.

KAWULA, S. (2005) Kształt rodziny współczesnej. Szkice familiologiczne. Toruń: Wydawnictwo Adam Marszałek.

KeYES, R. (2018) Czas postprawdy. Nieszczerość i oszustwa w życiu codziennym. Warszawa: PWN. 
KMIECIAK, B. (2018) 'Szaleństwo versus małżeństwo. Uwagi na tle orzeczenia Trybunału Konstytucyjnego w sprawie względnego zakazu zawierania małżeństw przez osoby chore psychicznie i upośledzone umysłowo', Prawo i Medycyna, 20(1), pp. 93-111.

KocIK, L. (2006) Rodzina w obliczu wartości i wzorów życia ponowoczesnego świata. Kraków: Oficyna Wydawnicza AFM.

KoŁAKOWSKI, L. (2003) 'Po co nam prawa człowieka?' Gazeta Wyborcza. 25-26 Oct.

KRASIEJKO, I. (2011) Praca socjalna $w$ praktyce asystenta rodziny. Przykład Podejścia Skoncentrowanego na Rozwiazaniach. $2^{\text {nd }}$ edn. Katowice: Śląsk.

KWAK, A. (2007) Rodzina $w$ dobie przemian. Małżeństwo i kohabitacja. Warszawa: ŻAK.

ŁĄCzKowsKA, M. (2005) 'Czy istnieje prawo do posiadania” dziecka?' in Haberko, J. and Łączkowska, M. (eds.) Prawne, medyczne i aksjologiczne aspekty wspomaganej prokreacji. Poznań: WPiA UAM.

ŁĄCZKOWSKA-PORAWSKA, M. (2019) Monogamiczność i heteroseksualność małżeństwa. Warszawa: Wydawnictwo INP PAN.

ŁĄCZKOWSKA, M. (2013) 'Charakter prawny rejestrowanego zwiazku partnerskiego w świetle polskich projektów regulacji', in Andrzejewski M. (ed.)

ŁĘTOWSKA, E. AND WOLEŃSKI, J. (2013) 'Instytucjonalizacja związków partnerskich a Konstytucja RP z 1997 r.', Państwo i Prawo, 2013/6.

MACIARZ, A. (2004) Macierzyństwo $w$ kontekście zmian społecznych. Warszawa: ŻAK.

MAZURKIEWICZ, J. (2012) 'Rozwodzić” jest przeciwieństwem zwodzić', czyli o potrzebie zasadniczej reformy prawa rozwodowego', in Pisuliński, J., Tereszkiewicz, P. and Zoll, F. (eds.) (2012) Rozprawy z prawa cywilnego, własności intelektualnej i prawa prywatnego międzynarodowego. Księga pamiątkowa dedykowana prof. B. Gawlikowi. Warszawa: Wolters Kluwer.

MAZURKIEWICZ, J. AND MYSIAK, P. (eds.) (2017) Nasciturus pro iam nato habetur: o ochronę dziecka poczętego i jego matki. Wrocław: Wydawca J. Mazurkiewicz.

MĄCZYŃSKI, A. (2013) 'Konstytucyjne i międzynarodowe uwarunkowania instytucjonalizacji związków homoseksualnych' in Andrzejewski M.(ed.).

MikruT, A. (2015) 'Małżeństwo i rodzicielstwo osób z niepełnosprawnością intelektualną w kontekście Konwencji o osobach niepełnosprawnych', Pedagogika Specjalna, no. 1, Available at: https://bit.ly/3ir5qDt (Accessed: 2 May 2021).

Millon-Delsol, C. (1995) Zasada pomocniczości. Kraków: Znak.

MORAWSKI, L. (1998) 'Prawa jednostki a dobro wspólne (liberalizm versus komunitaryzm)', Państwo i Prawo, 1998/1.

MostowiK, P. (2019) 'O żądaniach wpisu w polskim rejestrze stanu cywilnego zagranicznej fikcji prawnej pochodzenia dziecko od rodziców jednopłciowych', Forum Prawnicze, 56(6); https://doi.org/10.32082/fp.v6i56.206.

MurRAY, C.A. (2001) Bez korzeni: polityka społeczna USA 1950-1980. Poznań: Zysk S-ka.

NAZAR, M. (1993) Rozliczenia majątkowe konkubentów. Lublin: Lubelskie Wydawnictwo Prawnicze.

NiTECKI, S. (2008) Prawo do pomocy społecznej w polskim systemie prawnym. Warszawa: Wolters Kluwer.

NiTECKI, S. (2016) in Nitecki, S. and Wilk, A. Ustawa o wspieraniu rodziny i systemie pieczy zastępczej. Komentarz. Warszawa: Wolters Kluwer.

NowICKI, M.A. (2010) Wokół Konwencji Europejskiej. Komentarz do Europejskiej Konwencji Praw Człowieka. $5^{\text {th }}$ edn. Warszawa: Wolters Kluwer.

OLEJNICZAK, A. (1980) Materialnoprawne przesłanki udzielenia rozwodu. Poznań: Wydawnictwo UAM. 
OstAszeWSKA, A. AND NAGÓRKA A.J. (2012) 'Cechy stabilności małżeństwa. Statystyka rozwodów w Polsce na tle badań zagranicznych' in Kotlarska-Michalska, A. (ed.). Oblicza małżeństwa. Roczniki Socjologii Rodziny Vol. XXII, Wydawnictwo: Naukowe UAM.

PAWLICZAK, J. (2013) Zarejestrowany związek partnerski a małżeństwo. Warszawa: Wolters Kluwer.

PIETRZYKOWSKI, K. (2020) in K. Pietrzykowski (ed.) Kodeks rodzinny i opiekuńczy. Komentarz. $6^{\text {th }}$ edn. Warszawa: C.H. Beck.

Potocki, A. (2017) O Kościele także socjologicznie. Warszawa: PWN.

PRZYBYє, I. (2012) 'Wokół procesu (de)instytucjonalizacji małżeństwa w Polsce' in Kotlarska-Michalska, A. (ed.) Oblicza małżeństwa. Roczniki Socjologii Rodziny, Vol. XXII, Wydawnictwo: Naukowe UAM.

RoszKowsKi, W. (2019) Roztrzaskane lustro. Upadek cywilizacji zachodniej. Kraków: Biały Kruk.

RYMSZA M. (2003) 'Aktywna polityka społeczna w teorii i praktyce' in Kazimierczak T. Rymsza M. (eds.) (2003) W stronę aktywnej polityki społeczej. Warszawa: ISP.

RYMSZA, M. (2009) 'Małżeństwo nie jest sprawą prywatną', Więź, 2009/11-12.

SŁYK, J. (2017) in Osajda K. (ed.), Tom V. Kodeks rodzinny i opiekuńczy. Komentarz. Przepisy wprowadzające KRO. Warszawa: C.H. Beck.

SŁYK, J. (2019) 'Family Justice in Poland: An Outline of the Problem Situation and the Optimum Reform Direction', Prawo w Działaniu, 2019/38, pp. 54-64; https://doi.org/10.32041/ pwd.3803.

SMYCZYŃSKI, T. (1997) 'Małżeństwo konkordatowe' a Konstytucja (O potrzebie i zakresie nowelizacji Kodeksu rodzinnego i opiekuńczego)', Państwo i Prawo, 1997/5.

SMYCZYŃSKI, T. (1997a) 'Rodzina i prawo rodzinne $w$ świetle nowej Konstytucji RP', Państwo $i$ Prawo, 1997/11-12.

SMYCZYŃSKI, T. (1999) 'Prawo dziecka do wychowania się w rodzinie' in Smyczyński T. (ed.) (1999a).

SMYCZYŃSKI, T.(ed.) (1999a) Konwencja o prawach dziecka. Analiza i wykładnia. Poznań: ars boni et aeuqi.

SMYCZYŃSKI, T. (1999b) 'Pojęcie dziecka i jego podmiotowość' in Smyczyński, T. (ed.) (1999a).

SMYCZYŃSKI, T. (2009) 'Zagadnienia wprowadzające' in Smyczyński, T. (ed.) Prawo rodzinne i opiekuńcze. System Prawa Prywatnego, Vol. 11. $2^{\text {nd }}$ edn. Warszawa: INP PAN, C.H. Beck.

SMYCZYŃSKI, T. (ed.) (2011) Prawo rodzinne i opiekuńcze, System Prawa Prywatnego. Vol. 12, $2^{\text {nd }}$ edn. Warszawa: INP PAN, C.H. Beck.

SMYCZYŃSKI, T. (2012) 'Czy jest potrzebna Konwencja o Prawach Dziecka?' in Andrzejewski M. (ed.).

SMYCZYŃSKI T. (2013) 'Małżeństwo - konkubinat - związek partnrski' in Andrzejewski M. (ed.).

SMYCZYŃSKI T. (2018) Prawo rodzinne i opiekuńcze. $9^{\text {th }}$ edn. Warszawa: C.H. Beck.

SoKOŁOWSKI T. (1997) Skutki prawne rozwodu. Poznań: Wydawnictwo UAM.

SoкоŁOWSKI T. (2013) 'Dobro dziecka wobec rzekomego prawa do adopcji' in Andrzejewski M. (ed.)

STADNICZEŃKO, L.S. (2015) Konwencja o prawach dziecka. Wybór zagadnień (artykuły i komentarze). Warszawa: RPD.

StelmaCh, J., BożeK, B., SonieWickA, M. AND ZAŁUski, M. (2010) Paradoksy bioetyki prawniczej. Warszawa: Wolters Kluwer.

Stojanowska W. (2009) 'Rozwód’ in Smyczyński T. (ed.) Prawo rodzinne i opiekuńcze, System Prawa Prywatnego, Vol. 11. $2^{\text {nd }}$ edn. Warszawa: C.H. Beck, INP PAN. 
STRZEBIŃCZYK, J. 'WŁADZA RODZICIELSKA' IN SMYCZYŃSKI T. (ed.).

STRZELECKI, Z. (2015) 'Współczesne wyzwania demograficzne dla Europy i Polski' in Giermanowska, E., Racław, M. and Rymsza M. (eds.) Kwestia społeczna u progu XXI wieku. Księga jubileuszowa dla Profesor Józefiny Hrynkiewicz. Warszawa: Wydawnictwo UW.

SZLENDAK, T. (2010) Socjologia rodziny. Ewolucja, historia, zróżnicowanie. Warszawa: PWN.

SZUDLIŃSKA-KANOŚ, A. (2019) Polska polityka rodzinna $w$ okresie przemian. Kontekst krajowy i międzynarodowy. Kraków: ISP UJ.

SzUKALSKI, P. (2009) 'Czy w polsce nastąpi powrót do prostej zastępowalności pokoleń?', Acta Universitatis Lodziensis Folia Oeconomica, 2009/10, pp. 59-75.

ŚLEDZIŃSKA-SIMON, A. (2009) 'Adopcja dzieci przez pary homoseksualne', in Wieruszewski R. and Wyrzykowski M. (eds.) Orientacja seksualna i tożsamość płciowa. Warszawa: EuroPrawo.

TElUSIEWICZ, P. (2013) Służeban rola zwrotu 'rodzinny' w przepisach prawa polskiego. Lublin: Wydawnictwo KUL.

TElusiEwiCZ, P. (2019) 'Surrogate motherhood (urodzenie zastępcze) na tle fundamentówmaterialnego prawa rodzinnego' in Mostowik, P. (ed.) Fundamentalne i prawne problemy surrogate motherhood. Perspektywa polska. Warszawa: IWS.

TERLIKOWSKI, T. (2006) 'Przyszłość małżeństwa. W poszukiwaniu paradygmatu bardziej komunitarnego', Więź, 2006/9.

THE WORLD FACTBOOK. 2012.

TYSZKA, Z. (1973) 'Geneza i rozwój socjologii rodziny', Ruch Prawniczy, Ekonomiczny i Socjologiczny, no. 1.

TYSZKA, Z.(1997) System metodologiczny poznańskiej szkoły socjologicznych badań nad rodzina (stan aktualny). Poznań: UAM.

VARAUT, J.M. (1996) Możliwe lecz zakazane. O powinnościach prawa. Warszawa: PWN.

WASZYŃSKA, K. AND ZIELONA-JENEK, M. (2016), 'Zjawisko seksualizacji jako wyzwanie dla współczesnej edukacji', Studia Edukacyjne, 2016/39.

WiLDSTEIN, B. (2020) Bunt i afirmacja. Esej o naszych czasach. Kraków: PIW.

WIŚNIEWSKI, L. (2009) 'Zdanie odrębne', in Wieruszewski R. and Wyrzykowski M. (eds.) Orientacja seksualna i tożsamość płciowa. Aspekty prawne i społeczne. Warszawa: EuroPrawo.

ZACHARIASIEWICZ, M. (2019) 'Transkrypcja aktów urodzenia dzieci par jednopłciowych', Studia Prawno-Ekonomiczne, Vol. CXI.

ZEDLER, F. (1984) Sady rodzinne. Wybrane zagadnienia organizacyjne i procesowe. Warszawa: Wydawnictwo Prawnicze.

ZIELONA-JENEK, M. (2017) 'Seksualizacja - definicje, polemiki i próba rekonceptualizacji', Dziecko Krzywdzone, 2017/3.

ZIEMBIŃSKI, Z. (1982) Szkice z metodologii szczegółowych nauk prawnych. Warszawa-Poznań: PWN. 